\title{
Analysis of Land Use Changes and Land Suitability for Rice Fields in Tanjung Jabung Barat District
}

\author{
Latifah $^{1}$, Anis Tatik Maryani ${ }^{1}$, Hutwan Syarifuddin ${ }^{1}$, Soni Pratomo² \\ ${ }^{1}$ Universitas Jambi \\ Jl. H. A Manaf, Telainapura - Jambi 36122 \\ ${ }^{2}$ Universitas Adiwangsa Jambi \\ Jl. Sersan Muslim RT 24, The Hok, Jambi \\ *e-mail: latifahchandra5@gmail.com
}

\begin{abstract}
ABSTRAK
Konversi lahan pertanian ke non pertanian merupakan fenomena yang tidak dapat dihindari, oleh karena itu diperlukan upaya untuk mengatur penggunaan lahan. Tujuan penelitian ini adalah menganalisis terkait laju konversi lahan sawah dengan mengidentifikasi pola dan spasial perubahan lahan serta faktor-faktor yang mempengaruhinya, serta menganalisis kesesuaian dan ketersediaan lahan padi sawah dan kesesuaian lahan padi sawah existing dengan rencana pola ruang. Penelitian menggunakan data primer berupa peta tanah semi detail, dan data sekunder berupa data dan laporan pendukung. Alat analisis yang digunakan yaitu Sistem Informasi Geografis, dan regresi logistik biner. Berdasarkan hasil analisis menunjukkan bahwa keseluruhan pola perubahan penggunaan lahan berjumlah 26 pola perubahan dengan jumlah luas perubahan sebesar 127.154 ha $(25,81 \%)$, dimana luas sawah berkurang seluas 1,241 ha dalam kurun waktu 2010-2018. Faktor locational rent yang paling besar peluangnya menyebabkan konversi lahan sawah adalah jarak terhadap pusat kelurahan/desa dengan koefisien negatif $(-3,25461631)$. Kesesuaian lahan aktual padi sawah eksisting yang paling dominan adalah S1 (74,58\%) kemudian S3rf $(13,86 \%)$ dan S3r $(10,83 \%)$, S3e (0,55\%). Evaluasi keselarasan kesesuaian lahan aktual sawah eksisting dengan rencana pola ruang diperoleh kategori selaras $(67,65 \%)$ dan berpotensi selaras $(28,16 \%)$ dengan usulan rekomendasi yaitu sawah eksisting dapat menjadi salah satu pertimbangan untuk alokasi lahan pangan berkelanjutan dengan melakukan pengendalian secara ketat terhadap alih fungsi lahan sawah serta meningkatkan upaya pengelolaan untuk memperoleh hasil produksi padi yang lebih optimal dan sebagai bahan pertimbangan dalam peninjauan kembali rencana pola ruang pada RTRW.
\end{abstract}

Kata kunci : kesesuaian lahan; konversi lahan; padi sawah; regresi logistik biner; sistem informasi geografi

\begin{abstract}
Conversion of agricultural land to non-agriculture is an unavoidable phenomenon, therefore efforts are needed to regulate land use. The purpose of this study is to analyze the rate of conversion of paddy fields by identifying patterns and spatial changes in land and the factors that influence it, as well as analyzing the suitability and availability of lowland rice fields and the suitability of existing lowland rice fields with spatial pattern plans. The study used primary data in the form of semi-detailed soil maps, and secondary data in the form of supporting data and reports. The analytical tools used are Geographic Information Systems, and binary logistic regression. Based on the results of the analysis, it shows that the overall pattern of land use change is 26 patterns of change with a total change area of 127,154 ha (25.81\%), where the area of rice fields is reduced by 1,241 ha in the period 2010-2018. The locational rent factor that has the greatest chance of causing rice field conversion is the distance to the center of the kelurahan/village with a negative coefficient (-3.25461631). The most dominant actual land suitability for existing lowland rice is S1 (74.58\%) then S3rf (13.86\%) and S3r (10.83\%), S3e (0.55\%). Evaluation of the alignment of the actual land suitability of the existing rice fields with the spatial pattern plan obtained in the aligned category (67.65\%) and potentially aligned (28.16\%) with the proposed recommendation that existing rice fields can be one of the considerations for sustainable food land allocation by carrying out strict control on the conversion of paddy fields as well as increasing management efforts to obtain more optimal rice production results and as a material for consideration in reviewing the spatial planing in the RTRW.
\end{abstract}

Keywords: binary logistic regression; land conversion; land suitability; geographic information system; rice field

\section{Pendahuluan}

Alih fungsi lahan pertanian di Indonesia, merupakan suatu permasalahan serius dimana fenomena alih fungsi lahan pertanian ke non pertanian menjadi ancaman terhadap ketahanan pangan. Menurut Iqbal dan Sumaryanto (2007), alih fungsi lahan pertanian yang tidak terkendali apabila tidak ditanggulangi dapat mendatangkan permasalahan yang serius, antara lain dapat mengancam kapasitas penyediaan pangan. Konversi lahan pertanian menjadi masalah ketika lahan pertanian yang dialihfungsikan merupakan lahan pertanian produktif. Konversi lahan pertanian tersebut akan menyebabkan terjadinya perubahan pada kondisi lingkungan dan kehidupan sosial masyarakat.

Secara umum terdapat beberapa faktor yang mendorong konversi lahan pertanian dan diantaranya yaitu faktor pertumbuhan penduduk yang menyebabkan meningkatnya permintaan lahan untuk kebutuhan permukiman maupun aktifitas, sementara luas lahan yang ada tidak berubah. Data BPS Kabupaten Tanjung Jabung Barat 2018 menunjukkan bahwa jumlah penduduk di Kabupaten Tanjung Jabung Barat mencapai 278.741 jiwa pada tahun 2010 dan mengalami peningkatan menjadi 328.343 jiwa pada tahun 2018, selama kurun 2010-2018 terjadi pertumbuhan penduduk sebesar 2\%. Laju pertumbuhan penduduk tersebut diperkirakan menjadi salah satu penyebab perubahan penggunaan lahan pertanian yang bergeser pada aktifitas non pertanian yang lebih menguntungkan di wilayah Kabupaten Tanjung Jabung Barat.

Data Statistik menunjukkan bahwa Luas panen padi sawah di Kabupaten Tanjung Jabung Barat pada tahun 2018 tercatat seluas 9.569 hektar dengan produksi sebanyak 65.396 Ton GKG dengan produktivitas sebesar 6,8 ton/hektar. Mengingat luas Lahan pertanian di Kabupaten Tanjung Jabung Barat terus mengalami penurunan yang akan memberikan dampak terhadap ketersediaan pangan, dimana perubahan luas lahan sawah di Kabupaten Tanjung Jabung Barat antara tahun 2010 - 2018 dapat dilihat pada Gambar.1. 


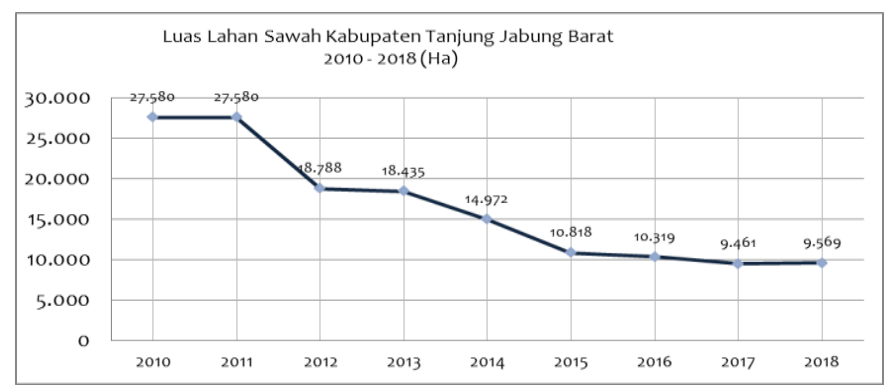

Gambar 1. Luas Lahan Sawah Kabupaten Tanjung Jabung Barat 2010 - 2018

(Sumber: BPS Tanjung Jabung Barat, 2019)

Untuk itu diperlukan analisis terkait laju konversi lahan sawah dengan mengidentifikasi pola dan spasial perubahan lahan serta faktor-faktor yang mempengaruhinya.

\section{Metode Penelitian}

\subsection{Analisis perubahan penggunaan lahan}

Analisis perubahan penggunaan lahan dilakukan dengan metode tumpangsusun (overlay) antara peta penggunaan lahan Kabupaten Tanjung Jabung Barat tahun 2010 dan 2018 dengan skala 1:50.000 untuk memperoleh matriks transisi dan peta perubahan penggunaan lahan. Peta penggunaan lahan dari kedua titik tahun dilakukan analisis untuk memperoleh informasi dari penggunaan dan ketersediaan lahan, dimana peta pada beberapa titik tahun sebelumnya bila ditumpangsusunkan (overlay) dengan peta administrasi, dapat memberikan informasi perubahan penggunaan lahan. Tahapan yang dilalui dalam proses pemetaan penggunaan lahan serta perubahannya dengan Geographical Information System (GIS) adalah: (a) Komputerisasi data, (b) Pengolahan basis data, dan (c) Peta informasi perubahan penggunaan lahan.

\subsection{Analisis faktor yang mempengaruhi perubahan penggunaan lahan}

Analisis faktor-faktor penyebab perubahan penggunaan lahan sawah dilakukan dengan menggunakan regresi logistik biner dimana variabel bebas bersifat biner dan direpresentasikan dengan nilai 0 yang menunjukkan tidak ada perubahan lahan sawah dan nilai 1 berarti ada perubahan sawah menjadi penggunaan lahan tertentu.

Data dari hasil peta perubahan penggunaan lahan ditumpangsusunkan (overlay) dengan data faktor-faktor yang diduga dapat mempengaruhi perubahan penggunaan lahan. Pada setiap tipe perubahan penggunaan lahan ke tipe penggunaan lahan lainnya dapat dicari peluang perubahannya dengan persamaan logit model (Susilo, 2006) sebagai berikut:

$$
\mathrm{Y}=\alpha+\beta 1 \mathrm{X} 1+\beta 2 \mathrm{X} 2+\beta 3 \mathrm{X} 3+\ldots \ldots+\beta 6 \mathrm{X} 6
$$

Dimana:

$\mathrm{Y} \quad=$ Probabilitas terjadinya perubahan lahan sawah

$\alpha=$ Konstanta persamaan regresi linier

$\beta 1 \ldots \beta 6=$ Koefisien dari faktor prediktor 1 hingga 6

$\mathrm{X} 1=$ Kepadatan Penduduk

$\mathrm{X} 2=$ Jarak dari jalan provinsi

$\mathrm{X} 3=$ Jarak dari jalan kabupaten

$\mathrm{X} 4=$ Jarak dari sungai

X5 = Jarak dari ibukota kecamatan

X6 = Jarak dari ibukota kelurahan/desa
Nilai "Y" atau peluang perubahan penggunaan lahan diperoleh dengan menggunakan persamaan berikut: Logit $(\mathrm{pi})=\operatorname{Ln}(\mathrm{P} /(1-\mathrm{P}))$

Dimana :

$\mathrm{P} \quad=$ peluang bahwa $\mathrm{Y}=1$

Logit pi pada dasarnya merupakan natural logaritma (ln) dari odd perubahan, dimana odd merupakan suatu indeks yang menyatakan peluang terjadi atau tidak terjadinya suatu peristiwa. Dalam hal ini yang dimaksud dengan peristiwa adalah perubahan penggunaan lahan sawah (Yudarwati, 2016).

\subsection{Analisis kesesuaian dan ketersediaan lahan sawah}

Penilaian kesesuaian lahan dilakukan terhadap hasil kompilasi data karakteristik dan kualitas lahan yang ada yang bersumber dari peta tanah skala 1:50.000 yang diperoleh dari BBSDLP, curah hujan dan kelas lereng. Data tersebut dikompilasi dengan menggunakan software ArcGIS sehingga dihasilkan satuan lahan homogen. Selanjutnya dilakukan proses matching antara karakteristik lahan dengan kriteria kesesuaian lahan untuk tanaman padi sawah yang merujuk kepada kriteria kesesuaian lahan dari Hardjowigeno dan Widiatmaka (2007). Tahapan pertama dari analisis ini adalah dengan menyusun satuan peta lahan yang didasarkan pada peta tanah skala 1:50.000 dari BBSDLP. Karakteristik lahan yang terkait dengan kriteria kesesuaian lahan untuk masingmasing satuan lahan diperoleh dengan cara mengevaluasi setiap satuan peta lahan berdasarkan kriteria kesesuaian lahan untuk tanaman padi sawah dengan membandingkan setiap karakteristik dengan parameter yang telah ditetapkan sehingga akan didapat kelas dari setiap jenis satuan peta lahan yaitu kelas S1, S2, S3, N1 dan N2.

Analisis ketersediaan lahan menggunakan data berupa peta penggunaan lahan tahun 2018, peta kesesuaian lahan dan peta kawasan hutan tahun 2017 digunakan untuk melihat kawasan hutan lindung ataupun taman nasional, kawasan hutan primer, dan kawasan hutan produksi di wilayah Kabupaten Tanjung Jabung Barat. Ketiga peta tersebut dilakukan proses overlay, kemudian hasil overlay dari petapeta tersebut memberikan informasi lahan yang sesuai tersedia dan merupakan lahan yang secara legalitas sesuai dan mempunyai potensi untuk perencanaan pengembangan pertanian khususnya untuk tanaman padi sawah. Kriteria ketersediaan lahan untuk pengembangan tanaman padi sawah disajikan pada Tabel 1. Analisis kesesuaian lahan dan ketersediaan lahan telah digunakan untuk meneliti potensi pengembangan komoditas tanaman pangan (Keratorof et al., 2016) dan pengembangan lahan sawah (Nurdin et al., 2016).

\subsection{Evaluasi keselarasan dan kesesuaian lahan aktual sawah dengan rencana pola ruang}

Analisis ini dilakukan dengan melakukan overlay antara peta kesesuaian lahan aktual sawah tahun 2018 terhadap peta rencana pola ruang dan diperoleh sebuah peta yang akan dijadikan sebagai basis data dalam evaluasi keselarasan kesesuaian lahan aktual sawah eksisting dengan rencana pola ruang.

Basis data yang di dalamnya terdapat atribut pola ruang dan kesesuaian lahan aktual selanjutnya diolah pada software Microsoft excel. Pengolahan atribut dengan menambahkan kolom baru yang berisi informasi mengenai jenis penggunaan lahan yang berada pada kawasan-kawasan yang telah ditetapkan dalam rencana pola ruang (Tejaningrum, 2016). Output yang akan didapat yaitu berupa peta yang telah 
diklasifikasikan berdasarkan keselarasan antara kesesuaian lahan dengan rencana pola ruang, yang dibagi menjadi tiga kelas yaitu: Selaras (S), Potensi Selaras (PS) dan Tidak Selaras (TS).

\section{Hasil dan Pembahasan}

\subsection{Perubahan Penggunaan Lahan dan Pola Perubahannya}

Perubahan penggunaan lahan merupakan bertambahnya suatu penggunaan lahan dari satu sisi penggunaan ke penggunaan yang lain dengan diikuti oleh berkurangnya tipe penggunaan yang lain dari satu waktu ke waktu lainnya (Agus, 2004). Penggunaan lahan di Kabupaten Tanjung Jabung Barat pada periode tahun 2010 - 2018 menunjukkan penggunaan lahan hutan di Kabupaten Tanjung Jabung Barat yang cenderung terus menurun dengan diikuti penambahan pada Hutan Tanaman Industri (HTI) seluas 73.110 ha dan Kelapa Sawit seluas $57.479 \mathrm{Ha}$ (Gambar 2). Menurunnya luas lahan hutan akibat peralihan fungsi hutan (deforestation), baik untuk pemukiman penduduk maupun untuk perluasan areal perkebunan dan pertanian (Jusmaliani, 2008 dalam Oksana et al., 2012). Hal tersebut dikarenakan lahan perkebunan memberikan nilai ekonomi yang lebih tinggi dibandingkan lahan hutan.

Tabel 1. Kriteria ketersediaan lahan untuk pengembangan tanaman padi

\begin{tabular}{llll}
\hline No & \multicolumn{1}{c}{ Jenis peta } & \multicolumn{1}{c}{ Tersedia } & Tidak tersedia \\
\hline 1 & $\begin{array}{l}\text { Peta penggunaan } \\
\text { lahan tahun 2018 }\end{array}$ & $\begin{array}{l}\text { Kebun campuran, } \\
\text { sawah, semak } \\
\text { belukar, tanaman } \\
\text { semusim dan tanah } \\
\text { terbuka }\end{array}$ & $\begin{array}{l}\text { Permukiman, } \\
\text { perkebunan, } \\
\text { sungai, tambak. }\end{array}$ \\
& & S1, S2, S3 & N1, N2 \\
2 & $\begin{array}{l}\text { Peta kesesuaian } \\
\text { lahan }\end{array}$ & - & Hutan Lindung, \\
3 & $\begin{array}{l}\text { Peta Kawasan } \\
\text { Hutan Tahun 2017 }\end{array}$ & HLG, dan HP \\
\hline
\end{tabular}

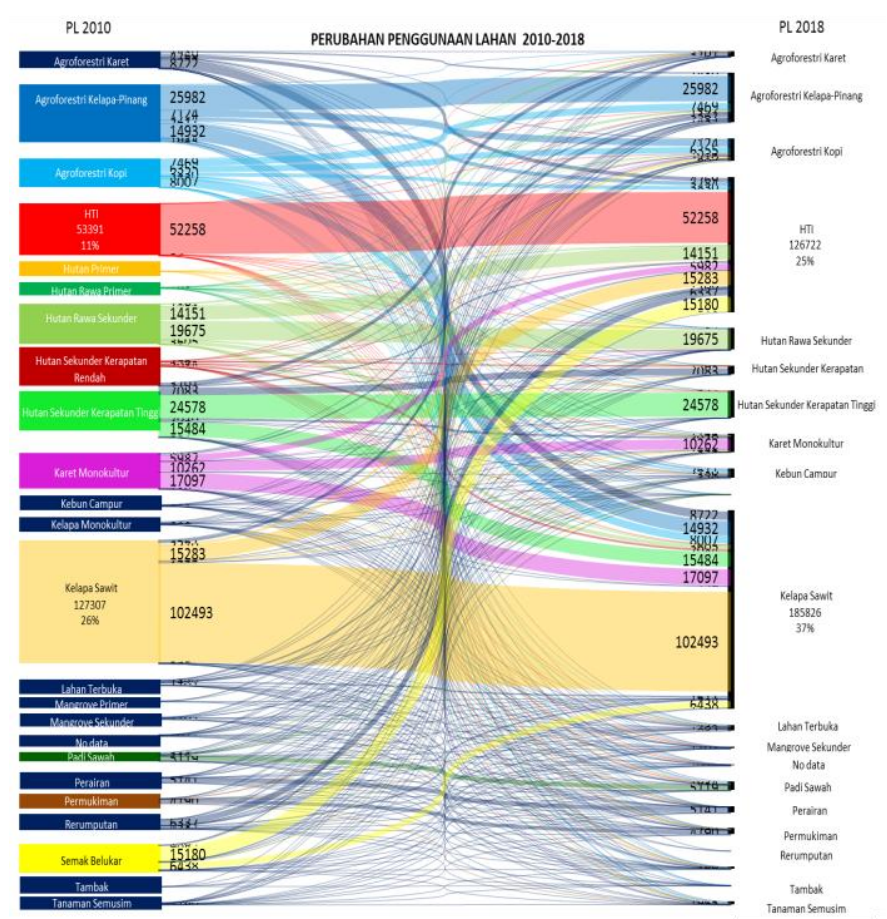

Gambar 2. Luas perubahan penggunaan lahan dari tahun $2010-2018$

\subsection{Pengaruh Jumlah Penduduk, faktor-faktor jarak terhadap perubahan penggunaan lahan padi sawah}

Analisis regresi logistik biner digunakan untuk menguji kepadatan penduduk dan faktor jarak yang diasumsikan berpengaruh terhadap perubahan penggunaan lahan sawah. Overlay antara perubahan penggunaan lahan sawah dari tahun 2010 hingga 2018 dengan faktor jumlah penduduk dan beberapa faktor jarak menghasilkan persamaan regresi sebagai berikut:

Logit (lahan_sawah_berubah) = $-1.2343+$ $\left(2.154676 * k p d t n \_p n d d k\right) \quad-\quad(2.415526 *$ jln_kab) + $\left(0.789881 * j l n \_p r o v\right) \quad-\quad(2.021491 *$ pus_kec $)$ (3.254616*pus_kel_des) - $(0.759544 *$ sungai $)$.

Hasil yang diperoleh dari 6 faktor tersebut memiliki nilai koefisien yang berbeda. Koefisien dari faktor-faktor yang menyebabkan perubahan penggunaan lahan masing-masing disajikan pada Tabel 2.

Tabel 2. Koefisien faktor penduduk dan aksesibilitas terhadap perubahan penggunaan lahan sawah

\begin{tabular}{cllr}
\hline No. & Faktor penyebab & Kode & Koefisien \\
\hline 1. & Konstanta persamaan & & $-1,23428885$ \\
2. & Kepadatan penduduk & kpdtn_pnddk & 2,15467609 \\
3. & Jarak terhadap jalan kabupaten & jln_kab_ & $-2,41552608$ \\
4. & Jarak terhadap jalan provinsi & jln_prov & 0,78988070 \\
5. & Jarakterhadap pusat kecamatan & pus_kec & $-2,02149110$ \\
6. & Jarakterhadap pusat kelurahan/desa & pus_kel_des & $-3,25461631$ \\
7. & Jarakterhadap sungai & sungai & $-0,75954400$ \\
\hline
\end{tabular}

Koefisien regresi positif (+) menandakan bahwa semakin besar nilai dari variable independen maka semakin besar kemungkinan terjadi perubahan penggunaan lahan pada lokasi tersebut. Sebaliknya, jika koefisien regresinya negatif (), menunjukkan bahwa semakin kecil nilai variable independen maka semakin besar kemungkinan perubahan penggunaan lahan pada lokasi tersebut.

\subsection{Analisis kesesuaian dan ketersediaan lahan sawah}

Penilaian kesesuaian lahan dilakukan baik secara aktual maupun potensial. Kesesuaian lahan aktual (current suitability) adalah penilaian kesesuaian lahan berdasarkan data sifat biofisik tanah atau belum mempertimbangkan usaha perbaikan dan tingkat pengelolaan yang dapat dilakukan untuk mengatasi kendala atau faktor-faktor pembatas yang ada di setiap satuan peta.

Tidak semua parameter kualitas dan karakteristik lahan digunakan dalam melakukan penilaian kesesuaian lahan aktual berdasarkan kriteria kesesuaian lahan untuk tanaman padi sawah menurut Hardjowigeno dan Widiatmaka, (2007). Data karakteristik lahan yang digunakan antara lain; 1) temperatur rata-rata (t); 2) ketersediaan air (w);3) media perakaran (r); 4) retensi hara (f); dan 5) tingkat bahaya erosi (e). Temperatur rata-rata di wilayah penelitian termasuk ke dalam kelas S1 dimana suhu udara rata-rata di Kabupaten Tanjung Jabung Barat berkisar antara $26.9^{\circ} \mathrm{C}-29^{\circ} \mathrm{C}$, kemudian untuk karakteristik kemiringan lereng di Kabupaten Tanjung Jabung Barat sekitar 49,55\% berada pada kelas S1 dengan kemiringan lereng 0 - 3\%, lalu 9,38\% termasuk pada kelas S2, kemudian $20,75 \%$ termasuk kelas S3, 8,81\% kelas N1, 10,47\% kelas N2 dan sisanya $1,05 \%$ merupakan tubuh air dan permukiman. 
Tabel 3. Kesesuaian lahan aktual padi sawah di Kabupaten Tanjung Jabung Barat

\begin{tabular}{|c|c|c|c|}
\hline \multirow{2}{*}{$\begin{array}{c}\text { Subkelas kesesuaian } \\
\text { lahan }\end{array}$} & \multirow{2}{*}{$\begin{array}{r}\text { Satuan Peta Lahan } \\
(\mathrm{SPL})\end{array}$} & \multicolumn{2}{|c|}{ Luas } \\
\hline & & ha & $\%$ \\
\hline S1 & 4.5 & 80,199 & 31.27 \\
\hline S2re & $28,29,30,32,41$ & 31,197 & 12.16 \\
\hline S2rf & 1 & 1,054 & 0.41 \\
\hline $\mathrm{S}_{3} \mathrm{r}$ & $, 16,20,21,2223,24,25,39$ & 30,625 & 11.94 \\
\hline$s_{3} f$ & 10 & 4,122 & 1.61 \\
\hline $\mathrm{S}_{3} \mathrm{e}$ & 18 & 347 & 0.14 \\
\hline S3rf & $2,3,8,9,40$ & 42,904 & 16.73 \\
\hline S3re & $17,26,27,38$ & 189 & 0.07 \\
\hline S3rfe & 31 & 30,760 & 11.99 \\
\hline N1r & 6,7 & 2,119 & 0.83 \\
\hline N1e & $11,12,19,33,34,35,42$ & 24,682 & 9.62 \\
\hline N2e & $13,14,36,37,44$ & 8,271 & 3.22 \\
\hline & Jumlah & 256,469 & 100.0 \\
\hline
\end{tabular}

Lahan yang sesuai dan tersedia merupakan lahan yang memiliki kesesuaian untuk padi sawah dan berada pada penggunaan lahan sawah, semak, belukar, kebun campuran dan tanah terbuka sementara dan tidak termasuk ke kawasan hutan. Lahan aktual yang sesuai dan tersedia untuk tanaman padi sawah berdasarkan hasil analisis ketersediaan lahan, diperoleh luas sawah yang sesuai dan tersedia seluas 25.251 ha. Peta kesesuaian dan ketersediaan lahan untuk tanaman padi sawah secara spasial di Kabupaten Tanjung Jabung Barat disajikan pada Gambar 3 .

Tabel 4. Kesesuaian dan ketersediaan lahan untuk tanaman padi sawah eksisting

\begin{tabular}{lllll}
\hline \multirow{2}{*}{ Kategori } & \multirow{2}{*}{ Tersedia } & & \multirow{2}{*}{ Tidak tersedia } & \multicolumn{2}{c}{ Luas sawah } \\
\cline { 4 - 5 } \cline { 3 - 5 } & & & ha & $\%$ \\
\hline Sesulai & $25,251 \mathrm{Ha}$ & 326,014 & 7,944 & 99,67 \\
Tidak sesual & 2,259 & 74,174 & 26 & 0,33 \\
\hline Jumlah (ha) & 27,510 & 400,188 & 7,970 & 100 \\
\hline
\end{tabular}

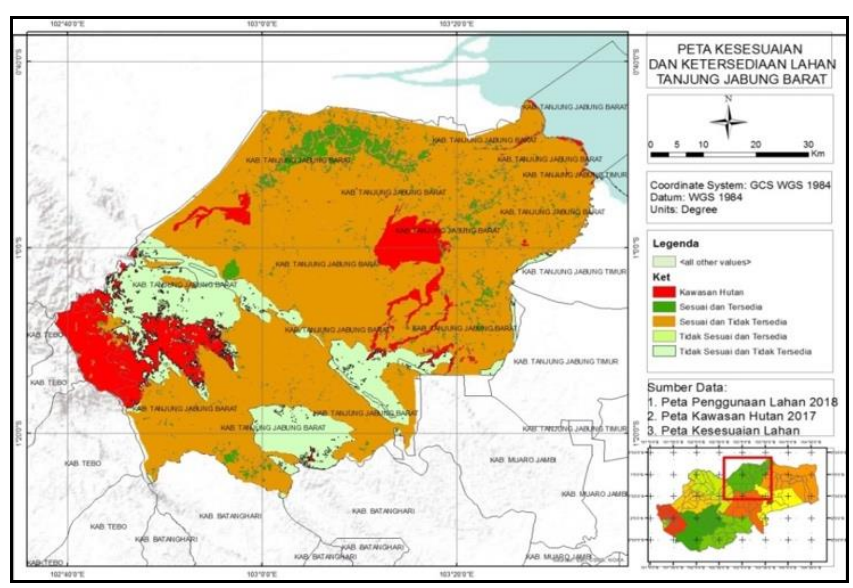

Gambar 3. Peta kesesuaian dan ketersediaan lahan untuk tanaman padi sawah

\subsection{Evaluasi keselarasan dan kesesuaian lahan aktual sawah dengan rencana pola ruang}

Dari hasil overlay antara peta kesesuaian lahan aktual sawah eksisting tahun 2018 dengan peta rencana pola ruang, diperoleh peta keselarasan kesesuaian lahan aktual sawah eksisting dengan rencana pola ruang yang kemudian dianalisis. Kajian evaluasi ini untuk menilai keselarasan antara kesesuaian lahan sawah aktual dan rencana pola ruang Kabupaten Tanjung Jabung Barat terhadap pemanfaatan lahan sawah eksisting di tahun 2018 sehingga dapat dilihat sejauh mana keselarasan penggunaan lahan sawah eksisting dengan rencana pola ruang dan juga kesesuaian lahan serta seberapa besar luasan lahannya.
Menurut hasil penelitian didapatkan informasi bahwa penggunaan lahan sawah di tahun 2018 memiliki nilai ketidakselarasan yang tidak terlalu besar, penggunaan lahan sawah yang selaras mencapai 5.317 ha $(67,65 \%)$, potensi selaras dengan luas 2.213 ha $(28,16 \%)$, Terdapat lahan sawah dengan luas 330 ha $(4,20 \%)$ yang masuk, hal ini dikarenakan lahan sawah tersebut berada di kawasan lindung pada rencana pola ruang.

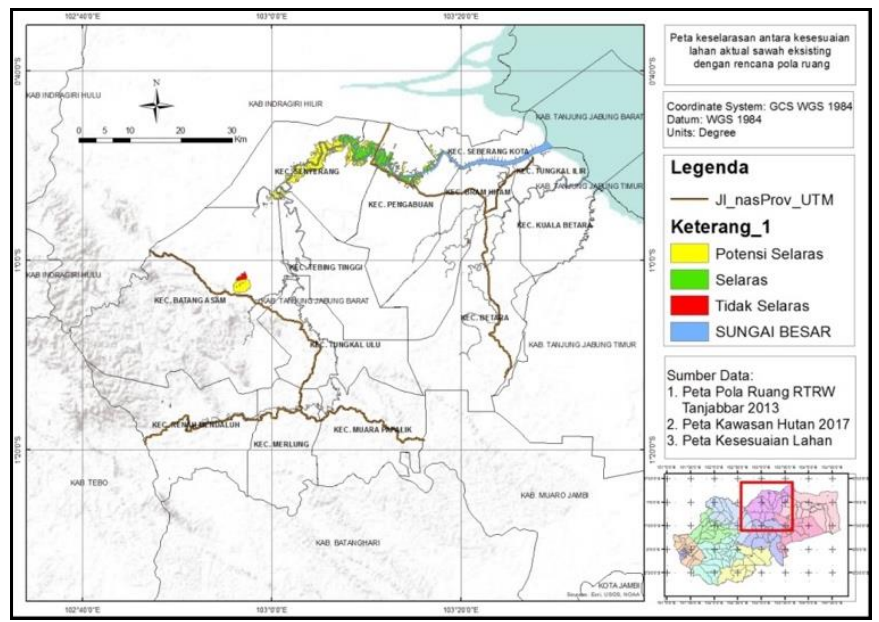

Gambar 4. Peta keselarasan antara kesesuaian lahan aktual sawah eksisting dengan rencana pola ruang

\section{Kesimpulan}

Keseluruhan pola perubahan penggunaan lahan berjumlah 26 pola perubahan dengan jumlah luas perubahan sebesar 127.154 ha $(25,81 \%)$, dimana luas sawah berkurang seluas 1,241 ha dalam kurun waktu 2010-2018. Faktor locational rent yang paling besar peluangnya menyebabkan konversi lahan sawah adalah jarak terhadap pusat kelurahan/desa dengan koefisien negatif (-3,25461631). Kesesuaian lahan aktual padi sawah eksisting yang paling dominan adalah S1 (74,58\%) kemudian S3rf $(13,86 \%)$ dan S3r $(10,83 \%)$, S3e $(0,55 \%)$. Evaluasi keselarasan kesesuaian lahan aktual sawah eksisting dengan rencana pola ruang diperoleh kategori selaras $(67,65 \%)$ dan berpotensi selaras $(28,16 \%)$ dengan usulan rekomendasi yaitu sawah eksisting dapat menjadi salah satu pertimbangan untuk alokasi lahan pangan berkelanjutan dengan melakukan pengendalian secara ketat terhadap alih fungsi lahan sawah serta meningkatkan upaya pengelolaan untuk memperoleh hasil produksi padi yang lebih optimal dan sebagai bahan pertimbangan dalam peninjauan kembali rencana pola ruang pada RTRW.

\section{Ucapan Terima Kasih}

Ucapan terima kasih ditujukan kepada teman-teman di Bidang Infrastruktur Wilayah Bappeda Provinsi Jambi yang telah membantu dalam pengadaan data dan diskusi.

\section{Daftar Pustaka}

[BPS] Badan Pusat Statistik Provinsi Jambi. 2018. Jambi Dalam Angka 2018. Jambi (ID): BadanPusat Statistik Provinsi Jambi. 
[BPS] Badan Pusat Statistik Provinsi Jambi. 2018. Jambi Dalam Angka 2018. Jambi (ID): BadanPusat Statistik Provinsi Jambi.

[BPS] Badan Pusat Statistik Kabupaten Tanjung Jabung Barat 2018.Tanjung Jabung Barat Dalam Angka 2018. Kuala Tungkal (ID): Badan Pusat Statistik Kabupaten Tanjung Jabung Barati.

Hardjowigeno, S, Widiatmaka. 2001. Kesesuaian Lahan dan Perencanaan Tata Guna Tanah. Bogor (ID): Jurusan Tanah, Fakultas Pertanian, Institut Pertanian Bogor.

Hardjowigeno, S, Widiatmaka. 2007. Evaluasi Kesesuaian Lahan dan Perencanaan Tata Guna Lahan. Yogyakarta (ID): Gadjah Mada University Press.

Iqbal, M dan Sumaryanto. (2007). Strategi Pengendalian Alih Fungsi Lahan Pertanian Bertumpu Pada Partisipasi Masyarakat. Bogor (ID): Pusat Analisis Sosial Ekonomi dan Kebijakan Pertanian.

Keratorof, M, Widiatmaka dan Suwardi. 2016. Aarahan Pengembangan Komoditas Tanaman Pangan Di Kabupaten Boven Digoel Provinsi Papua. Jurnal Pengelolaan Sumberdaya Alam dan Lingkungan. 6(2): 141-150.

Nurdin, S, Widiatmaka dan Munibah, K. 2016. Perencanaan Pengembangan Lahan Sawah di Kabupaten Kubu Raya. Jurnal Pengelolaan Sumberdaya Alam dan Lingkungan. 6(1): 1-12.

Pemerintah Kabupaten Tanjung Jabung Barat. 2013. PERDA Kabupaten Tanjung Jabung Barat Nomor 12 Tahun 2013 tentang Rencana Tata Ruang Wilayah Kabupaten Tanjung Jabung Barat Tahun 2013- 2033. Kuala Tungkal (ID): Sekretariat Daerah, Kabupaten Tanjung Jabung Barat.

Susilo, B. (2006). Geokomputasi Berbasis Sistem Informasi Geografi dan Cellular Automata untuk Pemodelan Dinamika Perubahan Penggunaan Lahan di Daerah Pinggiran Kota Yogyakarta, Laporan Penelitian. Yogyakarta (ID): Fakultas Geografi Universitas Gadjah Mada.

Tejaningrum, M.A. 2016. Pemodelan Perubahan Penggunaan Lahan Dan Keselarasan Penggunaan Lahan Terhadap RTRW Kabupaten Pontianak, Kalimantan Barat. [tesis]. Bogor (ID): SekolahPascasarjana, Institut Pertanian Bogor.

Yudarwati, R, Sitorus, S..RP, Munibah, K. 2016. Arahan Pengendalian Perubahan Penggunaan Lahan Menggunakan Metode Markov- Cellular Automata Di Kabupaten Cianjur. Jurnal Tataloka. 18(4): 211-221. 